\title{
A ARTE DO INVENTAR: ARTESANATOS DE PRESOS POLÍTICOS EM UM PRESÍDIO DA DITADURA CIVIL-MILITAR (1964-85)
}

\author{
Airton de Farias ${ }^{1}$
}

\section{Do suor do teu rosto comerás o teu pão}

Em 2013, o governo do Ceará desativou o Instituto Penal Paulo Sarasate (IPPS). As razões para tais foram as precariedades das estruturas físicas da prisão e as denúncias constantes de violações de direitos humanos que ali aconteciam. Celas semidestruídas, superlotação, fugas e revoltas dos internos eram problemas constantes.

Um ano antes da desativação do Paulo Sarasate, em 2012, houve no presídio uma cerimônia na qual uma placa foi descerrada simbolizando um pedido de desculpas do governo do Ceará aos expresos políticos mantidos no presídio na década de 1970. A inauguração da placa evidenciava um fato pouco conhecido dos cearenses, o de que o IPPS também fora um presídio político, local onde estiveram encarcerados os inimigos da ditadura civil-militar que vigorou no Brasil entre 1964-85. Ali, tais militantes, vistos como "terroristas", mantidos à parte dos demais presos e sob a vigilância de funcionários e agentes da ditadura, tiveram de enfrentar novos desafios, buscando melhores condições de vida ou de sobrevivência dentro dos cárceres. Ante a estrutura autoritária do presídio e da ditadura, os ativistas buscaram abrir brechas, forçaram fissuras, desenvolveram práticas, táticas, realizaram reconstruções e ressignificações, conforme entende Michel de Certeau ${ }^{2}$. Essas novas práticas tiveram relevos para a redefinição de suas identidades e projetos políticos.

Situado na região metropolitana de Fortaleza, no município de Itaitinga, o IPPS foi inaugurado a 12 de setembro de 1970, no final do governo cearense de Plácido Aderaldo Castelo (1966-70). Paulo Sarasate havia sido um professor e jornalista, fundador, em 1928, do jornal O Povo, ainda hoje em circulação como um dos maiores periódicos da capital cearense. Nascido em 1908, Sarasate destacarase na política local, tornando-se um dos principais líderes da UDN (União Democrática Nacional) e sendo eleito governador do estado para um mandato entre 1955 e 1958. Apoiaria o golpe de 64, gozando de boas relações com o primeiro presidente militar, nascido no Ceará, marechal Castelo Branco. Poderia ter até voltando a ocupar o cargo de governador em 1966, mas acabou preterido, por seu delicado estado de saúde. Não obstante, indicou um aliado para o cargo, o então obscuro deputado estadual Plácido Castelo. Sarasate faleceria em 1968. Assim, não surpreende a homenagem feita por Plácido Castelo ao mentor Paulo Sarasate, dando o nome deste a uma das principais obras de sua gestão.

Até a inauguração do Paulo Sarasate, o principal presídio de Fortaleza era a chamada Cadeia Pública do Ceará, construída ainda na época do Império, em 1866, e situada no centro da capital ${ }^{3}$. A precariedade dessa Cadeia, sua superlotação e a localização, dificultando reformas e ampliações, levaram o governo cearense a construir o IPPS, situado longe do perímetro urbano de Fortaleza. A partir do início de 1971, os presos da Cadeia Pública começaram a ser transferidos para o Paulo Sarasate, embora o presídio ainda não estivesse com suas construções concluídas. O processo de transferência se encerrou em $1973^{4}$.

\footnotetext{
${ }^{1}$ Doutor em História Social/Contemporânea II pela Universidade Federal Fluminense (UFF), com a pesquisa Pavilhão sete: experiências dos militantes de esquerda armada nos cárceres cearenses (1971-79), mestre em História Social e bacharel em direito pela Universidade Federal do Ceará (UFC) e licenciado em História pela Universidade Estadual do Ceará (UECE). Autor de mais 20 livros didáticos e paradidáticos de história, a exemplo de História do Ceará (Armazém da Cultura, 2014). Professor do Instituto Federal do Ceará (IFCE). E-mail: airtondefarias@yahoo.com.br

${ }^{2}$ CERTEAU, Michel de. A invenção do cotidiano. Petrópolis: Ed. Vozes, 2004.

${ }^{3}$ MARIZ, Silviana Fernandes. Oficina de Satanás: a Cadeia Pública de Fortaleza (1850-1889). 2004, 156 f. Dissertação (Mestrado em História) - Universidade Federal do Ceará, Fortaleza, 2004.

${ }^{4}$ NERES, Gabriela. IPPS: memórias encarceradas. 2015, 184f. Monografia (Graduação em Comunicação Social) Faculdade 7 de Setembro, Fortaleza, 2015; RIBEIRO, Francisco Moreira. O PCB no Ceará. Fortaleza: Edições UFC/ Stylus Comunicações, 1989.
} 
Não se conhece com exatidão o número de pessoas encarceradas por razões políticas no IPPS durante a década de 1970. Os arquivos do presídio foram destruídos nos anos 1990, queimados quando de revoltas dos presos comuns e boa parte da documentação da burocracia da ditadura não está disponível aos pesquisadores no Ceará. Em nossa pesquisa de doutorado, em um levantamento parcial, encontramos o nome de 63 pessoas mantidas presas no Paulo Sarasate em virtude de alguma militância política. Desse número, 44 eram de integrantes de organizações armadas. Compete enfatizar que é esse não é um dado definitivo, pela limitação dos documentos aos quais tivemos acessos. Possivelmente, o número seja um pouco maior.

A quantidade de presos políticos presentes ao Paulo Sarasate variou ano a ano. Pelos depoimentos de entrevistados, nos primeiros anos da década de 70, a quantidade de militantes, incluindo os não adeptos da luta armada, era de "cerca de 20 a 30 presos". Esse número foi diminuindo ao longo do decênio, pois muitos dos ativistas passavam apenas meses na espera do julgamento e eram absolvidos ou obtinham a liberdade condicional, enquanto outros, condenados, cumpriam as penas e deixavam o presídio. Na segunda metade dos anos 70 , com a distensão do regime, a quantidade de presos políticos foi sendo reduzida ainda mais, sobremaneira em 1978 e 1979, com a mudança da Lei de Segurança Nacional, em 1978, e a Lei da Anistia, de 1979. O jornal Diário de Pernambuco, de 22 de dezembro de 1977, cita 15 presos políticos no IPPS. O mesmo periódico, na edição de 3 de maio de 1978, fala em 10 internos. Já a edição de 14 de julho de 1979, refere-se a cinco presos políticos. Em 1980, havia apenas um militante encarcerado, transferido do IPPS para o quartel do Corpo de Bombeiros, nas proximidades do centro de Fortaleza: era José Sales de Oliveira, o último preso político a ser libertado no Brasil 5 .

Fora intensa no Ceará, entre 1968 e 1972, a atuação da guerrilha, especialmente de organizações a exemplo de Ação Libertadora Nacional (ALN) e Partido Comunista Brasileiro Revolucionário (PCBR). Os ativistas eram, em geral, homens, jovens, estudantes de classe média, inseridos nas tradições do fazer político cearense, marcado há séculos pela violência. A repressão da ditadura igualmente não foi pequena no estado. No começo dos anos 70, os agrupamentos acabaram desbaratos, com os militantes sendo torturados e presos. Condenados pela Justiça Militar, boa parte deles iria cumprir as sentenças no recém-inaugurado Instituto Penal Paulo Sarasate ${ }^{6}$.

Os primeiros presos políticos chegaram ao IPPS em 1971. Eram os militantes da Ação Libertadora Nacional, condenados à prisão perpétua ou a longas penas em virtude do caso de São Benedito. Neste município cearense, em agosto de 1970, militantes da ALN fizeram o "justiçamento" (morte de um "inimigo da revolução") do comerciante José Armando Rodrigues. O negociante era acusado de ter uma lista com os nomes de membros da organização revolucionária, ameaçando fazer a delação aos órgãos de repressão. Após o caso de São Benedito, a ALN foi desbaratada no Ceará, com a prisão de vários de seus membros.

No presídio novo, os ativistas foram alocados nas ruas/galerias do pavilhão sete (P7). A ditadura, embora não reconhecesse a existência de presos políticos no País, buscou manter os "terroristas" à parte no presídio, ainda que nos anos seguintes ocorressem eventuais contatos com os presos comuns, nos banhos de sol, nos jogos de futebol, etc. Essa separação se vinculava a uma preocupação da direção prisional, de evitar que ideias "subversivas, "contaminassem" outros detentos, bem como a uma reivindicação dos próprios ativistas, os quais buscavam deixar clara a condição de inimigos políticos mantidos encarcerados pela ditadura $e$ o temor da violência que marca a rotina dos presos comuns em presídios. Há também a questão da origem social dos militantes de esquerda, em geral, homens "estudados", de classe média, gente que não poderiam se misturar com os internos comuns, "pretos e pobres". Nem quando prendia seus inimigos políticos, o Estado brasileiro deixava de evidenciar o caráter classista e étnico do sistema carcerário.

Os militantes da esquerda armada, vistos como "terroristas" ou "subversivos" e submetidos, de início, a rigoroso controle por parte da direção prisional, buscaram formas de escapar e resistir a tal controle. Entre as maiores mobilizações dos presos políticos do IPPS estiveram as que reivindicavam os direitos de produzirem seus próprios alimentos e de trabalharem na confecção de peças artesanais.

\footnotetext{
${ }^{5}$ FARIAS, José Airton de. Pavilhão Sete: experiências dos militantes de esquerda armada nos cárceres cearenses (19711978). 2018, 348f. Tese (Doutorado em História) - Universidade Federal Fluminense, Niterói, 2018.

${ }^{6}$ FARIAS, José Airton de. Além das armas: guerrilheiros de esquerda no Ceará durante a Ditadura Militar. 2007, $201 \mathrm{f}$. Dissertação (Mestrado em História) - Universidade Federal do Ceará, Fortaleza, 2007. 
Após negociações com a direção do Paulo Sarasate, foi-lhes autorizados transformarem duas celas desocupadas do P7 em cozinha e oficina. "Com o tempo, começou a haver um certo diálogo com a direção, mas com dificuldade de liberação das coisas. Mas a gente conseguiu o artesanato, termos os instrumentos para fazer nosso artesanato", afirmou o ex-militante da ALN, Wiliam Montenegro ${ }^{7}$.

Pela natureza das atividades desenvolvidas numa oficina, os ativistas passaram a acessar e a manusear facas e outros objetos perfuro cortantes (pregos, tachas, estiletes, serras, etc.). A postura da direção foi de concessão e tolerância tácita com os presos políticos: "A oficina ficava na primeira ou segunda cela, não lembro bem... O artesanato foi uma conquista, porque tinha faca, né? Eles [da direção] liberaram, foi um "deixa rolar". Ninguém foi lá e disse "vocês podem ter faca", não. Nada disso. Deixa rolar". 8

Não obstante essa liberação, a oficina, bem como a cozinha (onde igualmente se manuseavam facas), ficava nas primeiras celas da rua dos presos políticos, nas proximidades do portão de entrada da galeria, área por onde transitavam funcionários e seguranças do presídio. Se estes eram coniventes com a oficina, provavelmente estavam de olho no que era produzido e nas armas manuseadas pelos ditos "subversivos".

\section{Arte encarcerada}

Ao longo dos anos, a produção de artesanato da oficina dos presos políticos do IPPS foi se qualificando e se diversificando. Houve a confecção de produtos como sapatos, sandálias, bolsas, sacolas, colares, cinturões, capangas (pequena bolsa de mão usada por homens nos anos 70 e início dos 80), pendentes de corda (para pendurar vasos de samambaias, cujo cultivo era moda nos anos 70 e 80), porta-lápis, canetas (revestidas com linhas), canecas (latas de cerveja envolvidas com linha ou couro) e até pequenos móveis de bambu (bancos). Exemplos de obras de artes podem ser citados, como desenhos, quadros de madeira ou de couro, em técnica de xilogravura e pirogravura. Foram técnicas desenvolvidas e aperfeiçoadas pelos presos com o passar dos anos por vários motivos. Algumas vezes, por suas próprias experiências e reflexões sobre como aprimorar a produção. Havia a contribuição possibilitada com a chegada de novos presos políticos, que traziam consigo as experiências de outros presídios Brasil afora - o ex-militante do PCBR, Mário Albuquerque disse, por exemplo, que a técnica de pirogravura no Paulo Sarasate foi incrementada com a vinda de José Genoíno (ligado então ao PCdoB e depois deputado federal e ministro do governo Lula) de São Paulo, em 1975. Outras vezes, as técnicas de confecção eram aprimoradas por influências, imitação até, pois os presos do IPPS recebiam objetos artesanais e artísticos de outros presídios, do mesmo modo que enviavam os seus. Ocorreu também de realizarem cursos de produção: Flávio Sampaio, que então presidia a secção local da Associação Brasileira de Artesãos e era amigo do ex-integrante da ALN, William Montenegro, chegou a dar um curso sobre uso de couro aos internos do IPPS, conforme relatou o mesmo Mário Albuquerque ${ }^{9}$ e constatamos na imprensa da época.

Alguns artistas cumpririam penas no IPPS, como o teatrólogo Oswald Barroso, em 1977-78, dando contribuição para a produção artesanal e artística. No que toca a produção artesanal, nenhum dos ativistas da esquerda armada havia exercido a atividade antes da prisão. Mas pelo que foi dito pelos entrevistados, aqueles militantes que haviam trabalhado anteriormente em ofícios manuais ficaram conhecidos por apresentar maior habilidade na produção artesanal dentro do IPPS. Um dos casos citados foi o de José Ferreira Lima, antigo militante da ALN. Ferreira ficou famoso entre os colegas pela habilidade com a qual produzia, em quantidade e qualidade, sapatos, sandálias, bolsas, etc., cujas vendas ajudavam a manter sua numerosa família. Havia sido têxtil, destacando-se na mobilização de sua categoria em meados dos anos 60, quando era membro do PCB. Caiu na chamada lista negra, ou seja, operários que as empresas não contratavam por serem "problemáticos". Essa uma prática muito comum das fábricas de Fortaleza à época ${ }^{10}$. Com o golpe de 64, a perseguição a Ferreira intensificouse. Sem emprego, por força das circunstâncias, virou metalúrgico. Por ironia, a pequena metalúrgica em que trabalhava foi subcontratada para produzir parte das grades do IPPS, quando da construção

\footnotetext{
${ }^{7}$ Entrevista com o ex-militante da ALN, Wiliam Montenegro, a 24 de setembro de 2016.

${ }^{8}$ Entrevista com o ex-militante da ALN, Wiliam Montenegro, a 24 de setembro de 2016.

${ }^{9}$ Entrevista com o ex-militante do PCBR, Mário Albuquerque, a 14 de abril de 2016.

${ }^{10}$ RIBEIRO, Francisco Moreira. O PCB no Ceará. Fortaleza: Edições UFC/ Stylus Comunicações, 1989.
} SÆCUlUM - Revista de HistóRIa [39]; João Pessoa, jul./dez. 2018. 
do presídio no final dos anos 1960. O mesmo local onde depois Ferreira cumpriria pena por seus crimes de "subversão". À curiosa coincidência, em tom de brincadeira, não perdoariam seus companheiros de cárceres, conforme contou Mário Albuquerque: "Porra, Ferreira, por que tu não botou pouca solda nessas grades?, costumávamos tirar sarro dele" [risos] ${ }^{11}$.

Os ganhos pecuniários do trabalho na oficina eram apenas daqueles que se dedicavam à labuta. Não havia uma obrigatoriedade para todos os militantes trabalharem na produção artesanal, como acontecia no caso da cozinha. Dedicar-se ao artesanato era de livre escolha do interno, pois nem todos tinham a habilidade ou interesse no ofício. Cabia também ao preso, através da família, adquirir a matéria-prima, produzir e vender as peças. Cada um tinha o seu dia e um horário flexível na oficina, trabalhando sozinho, via de regra. A entrega da matéria-prima pela família e o repasse da produção aconteciam nos dias de visitas, aos sábados.

Em posse da produção, os familiares buscavam vender as peças, negociando-as, não raro, com amigos e outros parentes, embora igualmente pudessem repassá-las a alguns estabelecimentos comerciais, dos quais recebiam até encomendas. Havia uma verdadeira rede de apoio e venda para os produtos feitos pelos presos políticos do IPPS. Embora nunca tenha apresentado grandes lucros, de início, pelas dificuldades próprias às vendas artesanais e por possivelmente se tratar de objetos produzidos por "subversivos", esse comércio era mais restrito, com poucos ganhos. Vale lembrar que a situação financeira das famílias dos presos políticos cada vez mais se agravava à proporção que a permanência dos maridos e pais no presídio se prolongava. Por outro lado, não foi desprezível a solidariedade de algumas pessoas nessa verdadeira rede informal de comércio de peças artesanais. Contou-nos Ernesto Sales, filho do ex-ativista da ALN, José Sales:

[Os lucros] ficavam lá em casa. Escoávamos a produção, sandálias, bolsas, talhas, móveis de couro com bambu, etc. A gente comprava a matéria-prima no Toinho do Mercado Central. A gente nunca conseguia pagar tudo que comprava de matéria prima, sempre estávamos com a corda no pescoço, se não fosse a generosidade desse Toinho na maioria das vezes. (...) Todo mundo sabia que éramos a família do [preso político] Sales ${ }^{12}$.

No final dos anos 1970, com a abertura política realizada pela ditadura e engajamento de mais setores da sociedade na campanha da Anistia e libertação dos presos políticos, parece ter existido uma maior procura pelo público e facilidades na negociação da produção artesanal dos presos políticos do IPPS. Adquirir uma das peças poderia ser visto como uma forma de apoiar aquelas causas. A comercialização dos produtos passou a acontecer em mais áreas públicas. Nadja Miranda de Albuquerque, irmã de Mário Albuquerque e participante da campanha da Anistia, disse que os familiares buscavam áreas onde houvesse grande concentração de populares, para melhor vender as peças e divulgar a situação política do País. Quando de um show do cantor carioca Martinho da Vila no Theatro José de Alencar, no centro de Fortaleza, os familiares não titubearam em montar uma barraquinha na calçada. Ao saber que havia pessoas vendendo artesanato de presos políticos do Ceará, o cantor mandou comprar todas as peças em sinal de apoio ${ }^{13}$.

A venda das peças foi favorecida pela conjuntura econômica local. Segundo Flávio Teles Cardoso $^{14}$, na segunda metade da década de 1970 e começo da década seguinte, houve um incremento da atividade comercial de artesanato em Fortaleza, inclusive com apoio do governo estadual. Surgiram, então, várias feiras na cidade, onde os artesãos podiam expor seus trabalhos $e$ comercializá-los. Os familiares dos presos políticos e, depois, os membros da campanha pela Anistia montavam barraquinhas nas feiras que passaram a acontecer em locais como o calçadão da Avenida Beira Mar, o Passeio Público e a Praça Portugal e vendiam o artesanato ${ }^{15}$.

\footnotetext{
${ }^{11}$ Entrevista com o ex-militante do PCBR, Mário Albuquerque, a 14 de abril de 2016.

${ }^{12}$ Conversa com Ernesto Sales, filho do ex-militante da ALN, José Sales de Oliveira, pelo grupo "Memorial IPPS" do aplicativo de comunicação WhatsApp, a 17/05/2017.

${ }^{13}$ Conversa com Nadja Miranda de Albuquerque, pelo grupo "Memorial IPPS" do aplicativo de comunicação WhatsApp, a $17 / 05 / 2017$

${ }^{14}$ CARDOSO, Flavio Teles. Traduzindo a tradição: a construção do significado do artesanato no Ceara contemporâneo (1987-2002). 2010, 130f. Dissertação (Mestrado em História) - Universidade Federal do Ceará, Fortaleza, 2010.

${ }^{15}$ Sobre os movimentos pela Anistia no Ceará, vide SOUZA, André Pinheiro de. Do Movimento Feminino pela Anistia 
Nesse aspecto, as peças artesanais e artísticas desenvolvidas pelos militantes iam além das possibilidades de obter algum dinheiro e preencher o tempo dos encarcerados no IPPS. Eram ressignificadas, na linha do entendimento de Certeau, conforme as práticas e apropriações dos indivíduos e grupos. Os objetos de artesanato constituíam-se signos, usando a definição da semiótica, ou seja, meios de fazer a representação mental de um objeto, de uma ideia, de um desejo, atribuindo um valor, significado ou sentido, de modo a torná-los transmissíveis em forma de mensagem. Para a semiótica, temos a compressão de algo por meio de estímulo físico, um entendimento estabelecido entre o eu e o objeto. Em outras palavras, damos sentidos às coisas que nos rodeiam. Assim, por exemplo, o lugar em que se senta entendemos como uma cadeira. Signo é a referência do que temos em mente. Ao atribuir um sentido a algo, formam-se signos, portanto. O signo apresenta dois elementos, significado e significantes. Significado é o aspecto compreensível, a representação mental, o conceito, o ente abstrato do signo, para que serve o signo. A cadeira serve para sentar, o carro serve para se deslocar. O significante é o sentido verdadeiramente que se atribui ao signo, além do aspecto material. Qual a importância dessa cadeira, o que ela concretamente representa para as pessoas? E aí pode haver vários significantes, conforme indivíduos e grupos sociais, divergentes ou convergente e de acordo com elementos culturais, sociais, espaciais, históricos, etc. ${ }^{16}$.

Dessa forma, as peças de artesanato dos presos políticos do IPPS são signos, são objetos produzidos por internos de um presídio. O significado dessas peças, a priori, é utilitário ou estético. Se tem uma bolsa ou um par de chinelos para usá-los no dia a dia. O detalhe é sua significância. Para os presos políticos, para seus familiares e amigos, até para os agentes da ditadura, como veremos, as peças apresentavam outros sentidos, traziam outras implicações, de importância política, pessoal ou sentimental. Não por acaso, os parentes conservaram muitas dessas peças. Usavam-nas, sim, mas as consertavam, as guardavam com carinho, a ponto de se emocionar ao mostrá-las para a presente pesquisa.

As peças artesanais e artísticas dos presos políticos do Paulo Sarasate apresentavam várias significâncias. Eram instrumentos de divulgação, forma de comunicação dos presos com o mundo externo, denotando sua existência e condição de encarcerados, bem como denunciando e criticando a ditadura. Não era à toa que os ativistas, mesmo com seu trabalho individual, insistiam em gravar nas peças de couro e madeira a expressão Presos Políticos do Ceará, o que não foi aceito pela direção do IPPS - a ditadura não reconhecia a existência de inimigos políticos encarcerados no Brasil. Após intensa mobilização e negociação, chegou-se a um acordo, sendo aceito que se gravasse na peça a sigla PPCe, iniciais daquela expressão. Era uma forma de o presídio tentar esconder, pois, a existência dos presos políticos. Ao circularem fora do presídio, as peças furavam o discurso oficial, deixando claro que o regime, ao contrário do que propagava, mantinha, sim, presos políticos e que havia um regime de exceção no País. Ao serem comercializados numa "barraca dos presos políticos" - e os militantes pela Anistia e familiares faziam questão de deixar isso bem claro e explicar o porquê daquela sigla -, os objetos estavam cumprindo sua função de comunicação e denúncia.

Essa perspectiva de comunicação do artesanato, de divulgação da condição de presos políticos no IPPS, sem descartar outros sentidos, como o financeiro, levava até os presos a mudarem o processo de concepção e produção das peças no IPPS. Foi o que se deu quando de um congresso norte-nordeste de farmacêutico acontecido em Fortaleza, em 1976. Pelo depoimento de Mário Albuquerque, um dos organizadores do evento, Edson Pereira, membro do Conselho Regional de Farmácia e ligado ao PCdoB, articulou a encomenda de sacolas de couro para os farmacêuticos partícipes junto aos presos políticos do IPPS. Afora a ajuda financeira, a encomenda apresentava um posicionamento claramente político, de crítica ao regime. Naqueles meados dos anos 70 , quando se incrementava a oposição à ditadura, um evento com muitos participantes, repercutido pela imprensa e cujo material fora produzido por presos políticos, certamente chamava a atenção para a problemática. Em casos de grandes encomendas de artesanato, até pelo volume de peças a serem confeccionadas, alterava-se a

(MFPA-CE) ao Comitê Brasileiro pela Anistia (CBA-CE): as motivações e os caminhos percorridos pela anistia política no Ceará (1975 a 1980). 2012, 180 f. Dissertação (Mestrado em História). Universidade Estadual do Ceará, Centro de Humanidades, Fortaleza, 2012; DUARTE, Ana Rita Fonteles. Memórias em disputa e jogos de gênero: o Movimento Feminino pela Anistia no Ceará (1976-1979). 2009, 232f. Tese (Doutorado em História) - Universidade Federal de Santa Catarina, Florianópolis, 2009.

${ }^{16}$ SANTAELLA, Lúcia. O que é semiótica. São Paulo: Brasiliense, 2012. 
rotina da galeria dos militantes políticos do IPPS. Eles estabeleciam, então, jornadas especiais de trabalho na oficina, com a labuta e a divisão dos ganhos obtidos na venda passando a serem coletivas. Os presos políticos reuniam-se para discutir detalhes da produção (tamanho das peças, cores, desenhos, etc.) e estabeleciam qual o quinhão do total do pedido caberia a cada um produzir, acertando-se igualmente um horário especial de revezamento na oficina.

\section{Arte subversiva}

As peças de arte e artesanato igualmente serviam de meio para manifestar o pensamento político dos militantes, seus anseios, projetos. Encontramos várias peças em que se percebia, por exemplo, a defesa da liberdade e da Anistia, sobremaneira aquelas datadas do fim dos anos 70. Rarearam as peças do começo da década, exatamente quando era maior a presença de militantes que acreditavam na persistência $e$ viabilidade da luta armada. Verdade que a censura interna da direção do IPPS vetava a produção de peças com tal conteúdo, embora, pelo dito pelos entrevistados, a confecção tenha ocorrido. A dificuldade de encontrar peças da primeira metade da década de 1970 pode ser apenas coincidência, óbices naturais de se achar objetos mais antigos, alvos de censura, mais raros e de número reduzido, sem falar que muitos familiares dos presos não se preocuparam em preservar 0 artesanato. Estavam mais focados em obter algum ganho e conseguir a sobrevivência ante um quadro de dificuldades financeiras.

Mas pode não ser coincidência. Lembrando as lições de Jacque Le Goff ${ }^{17}$, o que sobreviveu não é o conjunto daquilo que existiu no passado, não foi conservado por mero acaso. É produto também de relações de forças, poderes e interesses. No caso das peças de artesanato dos presos políticos, valores sentimentais, mas igualmente políticos e de memórias reconstruídas ajudaram em suas manutenções. Talvez, para alguns dos ex-presos e parentes, não seja interessante conservar peças que denotam que os militantes, "radicais de esquerda", defendiam a conquista do poder institucional pelas armas $e$ violência, inclusive mesmo depois de serem presos. Nas reconstruções das memórias feitas pelas esquerdas, a partir da segunda metade dos anos 70, passou-se a enfatizar que a luta visava derrubar a ditadura e trazer de volta a democracia ${ }^{18}$. Alguns dos entrevistados adotaram esse discurso, quando, como demonstramos em nosso trabalho de doutorado, a autocrítica sobre a luta armada e o apoio à Anistia e à defesa pelo retorno da "democracia burguesa" foram alvos de acalorados debates entre os presos políticos do Paulo Sarasate ${ }^{19}$. Dessa forma, para coadunar memórias e identidades e projetos políticos, seria mais interessante conservar peças de artesanato que ratificassem os ideais de luta pela Anistia, concórdia e redemocratização do País.

\footnotetext{
${ }^{17}$ LE GOFF, Jacques. História e memória. Campinas, SP: Editora da Unicamp, 2003.

${ }^{18}$ AARÃO, Daniel. Ditadura e democracia no Brasil: do golpe de 1964 à Constituição de 1988. Rio de Janeiro: Zahar, 2014.

${ }^{19}$ FARIAS, Pavilhão Sete.... 

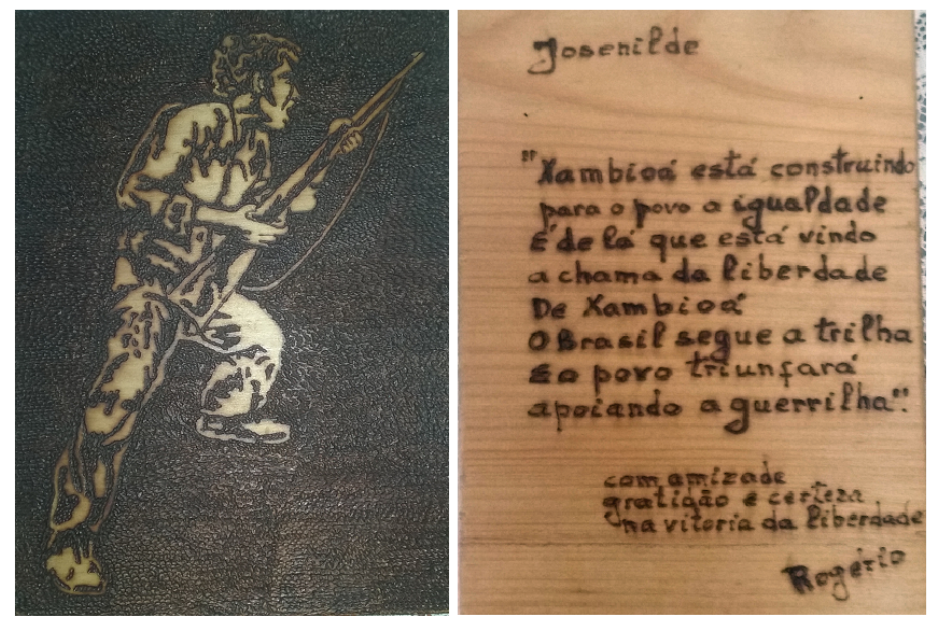

Imagem 1: xilogravura de Rogério Lustosa ${ }^{20}$

Entre os vários artesanatos aos quais tivemos acesso e fotografamos, conseguimos apenas uma única peça artística que denota explicitamente a crença de um preso político do IPPS na opção guerrilheira (imagem 1). Dona Josenilde Cunha, esposa do ex-membro da ALN, Fabiani Cunha, autorizou a fotografia de pequeno quadro, uma xilogravura, no qual o militante do PCdo $\mathrm{B}$, o maranhense Rogério Lustosa, lhe agradece pelo apoio na prisão (entreve no IPPS entre 1972-77) e manifesta crença no triunfo da guerrilha do Araguaia por meio de um poema. Na parte da frente do quadro, um homem, um jovem armado, pernas abertas, atento, em posição desafiadora e de ataque a mão direito está no gatilho da arma. A peça não é datada, mas presume-se que seja da primeira metade da década de 1970, pelas referências à guerrilha. Conforme Fabiani Cunha, era comum os militantes do PCdoB no IPPS mostrarem otimismo quanto à vitória no Araguaia, acompanhando entusiasmados pelo aparelho radiofônico os programas das Rádio Albânia e Rádio Pequim, as quais davam a entender que o PCdoB estava na iminência de ganhar a luta no norte do Brasil ${ }^{21}$.

Mais ainda: as peças artesanais e artísticas viraram mesmo elementos de vínculo e afinidade ideológica e política entre os adeptos das esquerdas. Como os militantes e os parentes buscavam deixar claro que se tratavam de objetos produzidos por ativistas mantidos presos pela ditadura, em muitas ocasiões os consumidores eram pessoas identificadas com as esquerdas ou que se solidarizavam com os encarcerados políticos. Assim, alguém, ao chegar num local e ver outrem com uma bolsa, capanga, sandálias, etc., daqueles modelos, entendia que era grande a possibilidade de a pessoa ter um parente preso político ou ser simpatizante das esquerdas. Foi o que disse Nadja Albuquerque ao mostrar algumas fotos de objetos confeccionados pelos militantes políticos encarcerados no Paulo Sarasate:

Essas carteiras, nós sempre estávamos usando com muito orgulho e eram reconhecidas principalmente nos cinemas de arte, onde a esquerda se encontrava. Meu Deus, estou recordando os velhos tempos. Meu Deus, como usávamos essas sandálias $^{22}$.

Por outro lado, a ditadura passou a ver as peças com mensagens políticas ou apenas assinadas pelos presos como prova de subversão e indisciplina. No Arquivo Público do Ceará tivemos acesso a um relatório confidencial do DOPS, de 1977, sobre irregularidades praticadas pelos "subversivos" no IPPS. O agente responsável pela investigação, Aluíso Figueiredo Gomes, infiltrou-se no Paulo Sarasate para produzir o relatório, ao qual anexou um cartaz (imagem 2), "imprimido em tipos de madeira (...) para o papel", acrescentando que "esse trabalho é feito pelos próprios presos políticos, os quais

\footnotetext{
20 "Josenilde 'Xambioá está construindo para o povo a igualdade/ É de lá que a chama da liberdade/ De Xambioá o Brasil segue a trilha E o povo triunfará apoiando a guerrilha. Com amizade, gratidão e certeza, uma vitória da liberdade. Rogério.”

21 Entrevista com o ex-militante da ALN, Fabiani Cunha, a 28 de março de 2017.

${ }^{22}$ Conversa com Nadja Miranda de Albuquerque, pelo grupo "Memorial IPPS" do aplicativo de comunicação WhatsApp, a $1705 / 2017$.
} 
distribuem com seus visitantes. Acrescente-se ainda, [sic] que observei que esses tipos de cartazes têm saída livre"23.

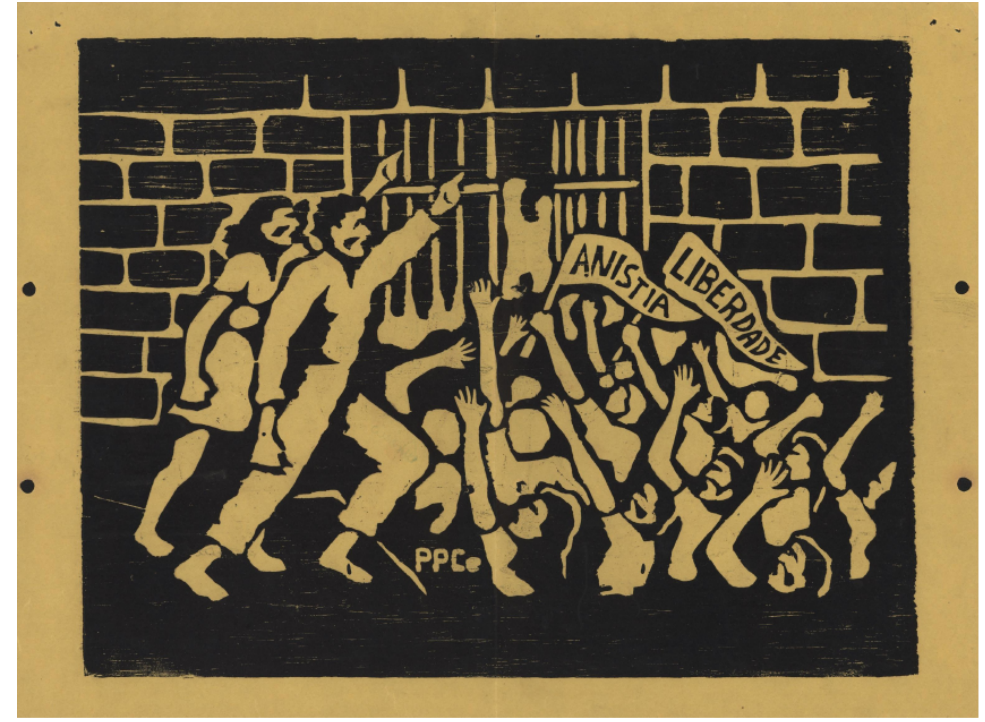

Imagem 2

Não deixa se chamar a atenção que, para demonstrar as eventuais ilegalidades as quais estavam acontecendo no presídio, o agente Aluísio Figueiredo se atentasse a um cartaz produzido a partir de uma xilogravura, que, assim, se tornava um instrumento da "subversão política", capaz de difundir mensagens contra o governo. Na imagem 2 , uma muralha, com portões de grades, uma prisão, parece ser atacada ou invadida por uma multidão, pessoas comuns, entre as quais mulheres, com flâmulas pedindo anistia e liberdade. Algumas das pessoas retratadas parecem furiosas e dispostas a agir, como se percebe por seus punhos cerrados e mãos e braços estendidos. Uma das pessoas estaria já abrindo os portões, como se convidando a massa a adentrar ou destruir a prisão. Um cartaz que incitava a rebelião e a queda do governo, pois, na significância atribuída pelo agente. Como prova material do crime praticado, o agente não apenas citou o cartaz, mas fez questão de anexar a imagem ao relatório. Deixou claro, pois, que a imagem apresentava um teor que atentava à ordem estabelecida, numa conduta que devia, assim, ser combatida, uma vez que os presos políticos estavam reproduzindo esse material, com a conivência ou omissão dos funcionários e diretores do IPPS.

Havia também no trabalho artesanal dos presos políticos do IPPS um sentido terapêutico, de desenvolver e expressar sensibilidades, sentimentos e aptidões artísticas dos militantes da esquerda revolucionária, homens vindos de um ambiente militarizado, de armas, força e que, além disso, foram criados numa sociedade machista, na qual a sensibilidade era concebida como "antimasculinas". Tanto o é que a produção de peças ocorreu não apenas na cela-oficina, cujo funcionamento foi autorizado pela direção do IPPS. As peças serviam para externar desabafos, sonhos, tristeza, afeto. Um exemplo pode ser encontrado nas peças de xadrez confeccionadas a partir de cabos de vassouras pelo ex-militante da ALN, Waldenilo Balaio. Pelos documentos analisados e depoimento de outros militantes e de sua filha, Sayonara Balaio, depreende-se que o preso político, ex-funcionário dos Correios e que já havia sido preso quando do golpe de 1964, ficou no IPPS entre 1971-72. Balaio passava horas em sua cela talhando as referidas peças com o manuseio de uma tampa de lata de sardinha, sinal que o uso de facas pelos presos políticos só era aceito dentro da oficina. Ao concluir o conjunto de peças do jogo, em vez de usá-lo com seus companheiros de presídio (o xadrez era uma das ocupações favoritas de alguns internos), Waldenilo presenteou-o, em sinal de apreço, à família, que conservou durante décadas as peças ${ }^{24}$.

O uso das obras para prestar homenagens e agradecimentos e expressar amizades e apoios foi mais

\footnotetext{
${ }^{23}$ Relatório de 15.08.1977, pasta do DOPS, Acervo do Arquivo Público do Ceará.

${ }^{24}$ Conversa com Sayonara Balaio, pelo grupo "Memorial IPPS" do aplicativo de comunicação WhatsApp, a 105/2017. 
uma significância das peças de artesanato ou de artes. No caso do artesanato, acontecia de bolsas, sapatos, etc. serem presenteados a familiares, amigos e apoiadores da causa da Anistia com dedicatórias especiais e assinaturas grafadas dos presos nas peças.

No caso das peças de arte para homenagens, como quadros de couro ou madeira, com técnicas de xilogravura ou pirogravura, sua confecção era acertada e produzida coletivamente, com cada preso, podendo, mesmo os que não dedicavam à oficina rotineiramente, contribuir, dar sugestões e trabalhar na produção de alguma peça. Ou seja, a produção de artes estimulava e possibilitava que outros presos também participassem do processo.

Mesmo se tratando de uma homenagem, o elemento político não deixava de estar presente na peça. Um exemplo do que se fala pode ser visto num cartão de feliz ano novo (1979) para Josenilde Cunha, esposa de Fabiani Cunha, que se destacou na Campanha da Anistia. Na frente do cartão (imagem 3), um desenho de mãos se erguendo, punhos cerrados de lutas, uma mão denotando cansaço, mas todas de braços amarrados. O significado é por demais óbvio: os presos políticos, o desejo de liberdade, a luta que então desenvolvia-se por uma "Anistia ampla e irrestrita", o desalento pelas dificuldades.

Era comum os encarcerados fazerem cópias de desenhos e peças recebidos de outros presídios. Os presos políticos do Paulo Sarasate, como disse William Montenegro ${ }^{25}$, enviavam e trocavam, via correio, peças artesanais e artísticas com militantes de locais diversos do Brasil, a exemplo de Recife, Rio de Janeiro e São Paulo. Tal intercâmbio da produção artesanal formou e fortaleceu os laços de sociabilidade e solidariedade política. Tais laços seriam de grande valia quando os encarcerados organizaram greves nacionais de fome, no caso as de maio de 1978, em solidariedade aos presos do presídio pernambucano do presídio de Itamaracá, e de agosto de 1979, contra a exclusão dos militantes da esquerda armada do projeto de Anistia do governo.

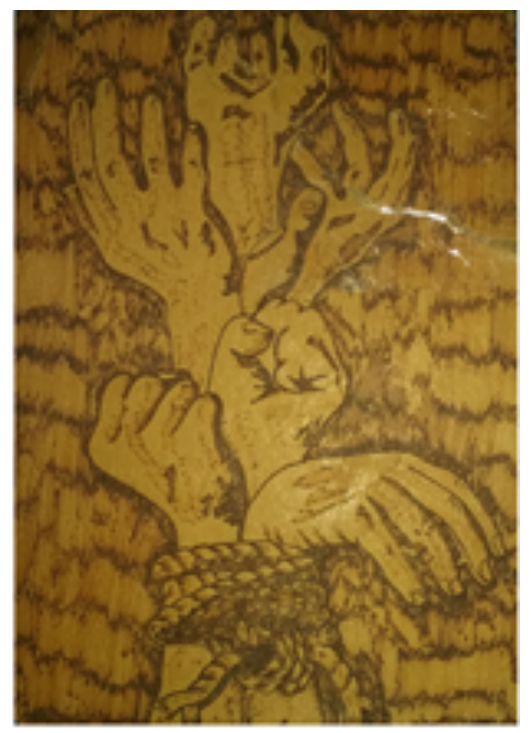

Imagem 3

Várias das peças de artesanato e artísticas de homenagens eram confeccionadas para datas especiais, como dia das mulheres, dia das mães, Natal, fim de ano, etc., sendo entregues aos apoiadores e familiares. Era grande a presença de mulheres, mães e irmãs, nas visitas aos presos do IPPS e no movimento pela Anistia ${ }^{26}$. Em referências àquelas datas, os militantes igualmente mandavam, por parentes ou pelos correios, peças artesanais ou cartões feitos em xilogravura para pessoas solidárias ou que poderiam ser solidárias à causa dos presos políticos. A intenção era não desperdiçar oportunidades para demonstrar à sociedade a existência de adversários políticos mantidos encarcerados pelo regime. William Montenegro nos mostrou um cartão, do ano de 1975, em que o bispo de Crateús-CE, Dom Antônio Fragoso, agradece aos presos políticos do Paulo Sarasate por

\footnotetext{
${ }^{25}$ Entrevista com o ex-militante da ALN, Wiliam Montenegro, a 24 de setembro de 2016.

${ }^{26}$ Vide SOUZA, Do Movimento Feminino... 
terem enviado um cartão no Natal do ano anterior e manifesta votos de feliz Páscoa e esperança em uma Anistia total. Os militantes também entregavam essas peças naquelas visitas tidas como especiais, a exemplo das do arcebispo de Fortaleza, Dom Aloísio Lorscheider, que anualmente se encontrava com os presos, comuns e políticos, do IPPS.

Com o incremento da Campanha da Anistia no final da década de 1970, a produção artesanal e artística não escapou à mobilização dos presos para obter, enfim, a saída dos cárceres. Conforme as reconstruções da memória que então ocorria entre as esquerdas, a mobilização não era mais pela revolução armada, mas, sim, em defensa das liberdades democráticas do País ${ }^{27}$. Não foi à toa que a maioria absoluta das peças de artesanatos aos quais tivemos acesso teve esse tema como foco. Uma produção tão intensa a ponto dos órgãos de repressão terem mandando secretamente um agente ao IPPS averiguar o que se passava no presídio, como visto acima. As famílias e integrantes dos movimentos pela Anistia foram importantes na divulgação desse artesanato engajado na Anistia.

A gente acabou se engajando na Campanha da Anistia, mas com cuidado com as famílias e as mulheres. O primeiro artesanato que fizemos para isso foi um medalhão, com um "a" com a boca aberta. Um "a" bem grande, só um "a". Então distribuímos esse medalhão com as famílias, com a seguinte recomendação: se a repressão perguntar, vocês dizem que é "a" de amor [risos]. Mas para os amigos vocês dizem que isso aqui é o "a" da Anistia ${ }^{28}$.

A produção de artesanato dos presos políticos do IPPS chegou a ser usada para denunciar a ditadura no exterior. Nadja Albuquerque nos mostrou foto de um jornal canadense, de 29 de abril de 1979, noticiando exposição de peças dos presos políticos cearenses organizada na Universidade de Ottawa. A exposição fora organizada por Pedro Albuquerque, exilado e ex-partícipe da guerrilha do Araguaia, na intenção de denunciar a ditadura brasileira, chamando a atenção para a greve de fome feita pelos militantes de esquerda naquele ano ${ }^{29}$.

\section{Conclusão}

Desativado em 2013 e situado no atual munícipio de Itaitinga-CE, na Região Metropolitana de Fortaleza, o Instituto Penal Paulo Sarasate (IPPS) serviu como prisão política durante a ditadura civilmilitar (1964-85). Ali, nos anos 70, os militantes de esquerda armada tiveram várias vivências, mudando suas identidades e projetos políticos. Usando de diversas táticas, os ativistas buscaram brechas na estrutura prisional da ditadura para obterem melhores condições de existência. Um de suas maiores mobilizações, exitosa, foi a de trabalhar na confecção de peças de artesanato e de arte. A comercialização de tais peças se tornou importante como fonte de renda para a manutenção das famílias dos presos políticos. Entendendo-se as peças como signos, percebe-se que apresentavam diversas significâncias e usos, conforme os grupos sociais.

Para os militantes de esquerda que compravam os produtos, era uma forma de vinculo e identidade ideológica. Os presos políticos tinham nas peças forma de denunciarem a ditadura reinante no país, que não hesitava em encarcerar seus adversários. Chegaram a ver as peças como forma de vincular a defesa da luta armada e a revolução, e, depois, no final dos anos 70, de endossar a campanha da Anistia. Foi mesmo forma de terapia para os internos, de desenvolverem sua sensibilidade e aptidões artísticas. A ditadura, por sua vez, chegou a ver as peças como forma de "subversão" e tentou censurar o artesanato, visto que não reconhecia a existência de presos políticos no País.

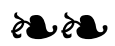

\footnotetext{
${ }^{27}$ FICO, Carlos. Brasil: a transição inconclusa. In: FICO, Carlos; ARAUJO, Maria Celina; GRIN, Mônica (orgs.). Violência na história: memória, trauma e reparação. Rio de Janeiro: Ponteio, 2012.

${ }^{28}$ Entrevista com o ex-militante da ALN, Fabiani Cunha, a 28 de março de 2017.

${ }^{29}$ Conversa com Nadja Miranda de Albuquerque, pelo grupo "Memorial IPPS" do aplicativo de comunicação WhatsApp, a $1705 / 2017$. 


\section{RESUMO}

O Instituto Penal Paulo Sarasate (IPPS), no Ceará, foi usado como prisão política durante a ditadura civil-militar (1964-85). Ali cumpriram pena militantes da esquerda armada nos anos 70 , os quais tiveram de se defrontar com novos desafios e vivências. Nesse processo, se redefiniram enquanto indivíduos e sujeitos políticos. Usando das brechas do sistema, os ativistas buscaram contornar as imposições do corpo dirigente prisional. Deram mesmo outros sentidos às estruturas físicas da prisão. Entre as maiores mobilizações dos presos políticos cearenses esteve a de produzirem peças de artesanato e de arte. As vendas das peças possibilitaram alguns recursos pecuniários que ajudavam no sustento das famílias dos encarcerados. Havia, porém, outras significâncias quanto àqueles objetos. Foi forma de identidade e vínculos entre os militantes de esquerda; forma dos encarcerados denunciarem a ditadura e a existência de presos políticos; forma dos presos políticos manifestarem seus posicionamentos políticos em favor da luta armada; foram vistas como manifestação de subversão pela ditadura; instrumentos de terapia e desenvolvimento de sensibilidades e aptidões artísticas; meios de endossar a Campanha da Anistia e estimular e agradecer os que se engajavam na defesa da democracia e libertação dos encarcerados políticos.

Palavras-chaves: Ditadura; Presos políticos; Artesanato.

\section{ABSTRACT}

The Paulo Sarasate Penal Institute (IPPS) in Ceará was used as a political prison during the civil-military dictatorship (1964-85). There, the left-wing militants of the armed left in the 70's, who had to face new challenges and experiences. In this process, they redefined themselves as individuals and political subjects. Using the breaches of the system, activists sought to circumvent the impositions of the prison corps. They even gave other senses to the physical structures of the prison. Among the major mobilizations of political prisoners of Ceará was to produce pieces of handicraft and art. The sales of the pieces made possible some pecuniary resources that helped to support the families of those incarcerated. There were, however, other significances as those objects. It was a form of identity and links between leftwing militants; prisoners to denounce the dictatorship and the existence of political prisoners; political prisoners to express their political positions in favor of armed struggle; were seen as a manifestation of subversion by the dictatorship; therapy instruments and development of artistic sensibilities and skills; means of endorsing the Amnesty Campaign and encouraging and thanking those who were engaged in defending democracy and releasing political prisoners.

Keywords: Dictatorship; Political prisoners; Crafts.

Artigo recebido em 28 mai. 2018.

Aprovado em 07 set. 2018. 
